\title{
Maintenance of Low Intrauterine Pressure by Estrogen and Progesterone during Late Pregnancy in Rats
}

\author{
Hiromichi Tamada, Hiroyuki Nakamura, and Junichi Mori \\ Department of Animal Reproduction, College of Agriculture, \\ University of Osaka Prefecture, Sakai, Osaka 591, Japan
}

(Accepted for publication July 17, 1989)

\begin{abstract}
Summary. This study was conducted to examine the effect of estrogen and/or progesterone on intrauterine pressure during late stages of pregnancy in rats. On day 14 of pregnancy, rats were sham-ovariectomized or ovariectomized, and one of the conceptuses in an individual rat was replaced by a balloon. The volume of the balloon was adjusted daily to that of the conceptus in intact pregnant rats. Each ovariectomized pregnant rat with an intrauterine balloon was injected daily with either vehicle (oil), estradiol, progesterone or combined estradiol and progesterone from day 14. The intrauterine pressure put on the balloon and the intraamniotic pressure in the conceptus with an alive fetus were measured on days 17 and 20. In some ovariectomized rats treated with either vehicle, estradiol or progesterone, the pressures could not be measured since these rats had the ruptured uterine wall over the balloon and/or no alive fetuses. Treatments with either estradiol or progesterone alone failed to lower the high intrauterine and intraamniotic pressures induced by ovariectomy. Administrations of combined estradiol and progesterone, however, reduced the pressures to levels in shamovariectomized animals. These results suggested that estrogen and progesterone act synergistically to maintain a low intrauterine pressure during late pregnancy.
\end{abstract}

KEY WORDS: ESTROGEN, PROGESTERONE, INTRAUTERINE PRESSURE, PREGNANCY, RAT.

Jpn J Anim Reprod 35, 193-197, 1989

In ovariectomized pregnant rats treated with progesterone alone, intrauterine pressure was abnormally high during late pregnancy (Ichikawa and Tamada, 1980; Hosoda and Ichikawa, 1984; Hosoda et al., 1984), and the fetus was often injured as the conceptus became elongated and cylindrical (Tamada and Ichikawa, 1980). Determination of passive length-tension relationship in the uterine strip (Tamada et al., 1984) indicated that an increase in intrauterine pressure is caused by the uterine collagenous framework stretched toward radial direction. Since estrogen treatments prevented the abnormalities described above (Ichikawa and Tamada, 1980; Tamada and Ichikawa, 1980; Tamada et al., 1984), the procedure may lower the intrauterine pressure in ovariectomized pregnant rats treated with progesterone alone to maintain successful pregnancy. The present study was undertaken to examine effect of estrogen and/or progesterone administration on intrauterine pressure in ovariectomized pregnant rats.

\section{Materials and Methods}

\section{Animals}

Adult virgin female Sprague-Dawley rats bred in our laboratory were kept in a temperaturecontrolled room $\left(24 \pm 1^{\circ} \mathrm{C}\right)$ that was artificially illuminated daily from 0500 to $1900 \mathrm{hr}$. They were mated with males at a body weight of $180-230 \mathrm{~g}$. The day on which spermatozoa were found in the vaginal smears was designated day 1 of pregnancy. On day 14 , rats were bilaterally sham-ovariectomized (S-OVX) or ovariectomized under ether anesthesia. Two of the conceptuses most adjacent to the uterotubal junction in the right uterine horn were removed through a small 
incision made on uterine wall and replaced by a thin latex balloon. The balloon was placed further away from the junction. The incision was closed with a purse-string suture. A polyethylene tube was connected to the balloon and exteriorized through an incision made on the cervical back skin. Each ovariectomized pregnant rat with an intrauterine balloon was given daily subcutaneous injections of either $0.2 \mathrm{ml}$ vehicle (sesame oil) (OVX-V), $0.2 \mu \mathrm{g}$ estradiol-17 $\beta$ (OVX-E ${ }_{2}$ ), $4 \mathrm{mg}$ progesterone (OVX-P) or combined estradiol-17 $\beta$ and progesterone $\left(\mathrm{OVX}-\mathrm{E}_{2} \mathrm{P}\right)$ from day 14 . No injections were given to S-OVX rats.

Changes in volume of a conceptus in intact pregnant rats were measured from days 14 through 19. The mean volume of saline displaced by a single fetus with the amniotic and allantoic sacs were shown in Table 1 . The

Table 1. Changes in volume of the conceptus during the late stages of pregnancy in rats

\begin{tabular}{ccc}
\hline $\begin{array}{c}\text { Day of } \\
\text { pregnancy }\end{array}$ & $\begin{array}{c}\text { No. of } \\
\text { rats }\end{array}$ & $\begin{array}{c}\text { Volume of } \\
\text { conceptus } \\
\text { (ml) }\end{array}$ \\
\hline 14 & $4(28)^{\mathrm{b}}$ & $0.33 \pm 0.02$ \\
15 & $4(44)$ & $0.64 \pm 0.01$ \\
16 & $4(33)$ & $0.93 \pm 0.02$ \\
17 & $5(56)$ & $1.35 \pm 0.07$ \\
18 & $4(43)$ & $1.99 \pm 0.07$ \\
19 & $4(31)$ & $2.92 \pm 0.03$ \\
\hline
\end{tabular}

a An average volume of the conceptus was determined in each litter, and values are means \pm SEM.

b Total number of conceptuses in each group.

volume of the intrauterine balloon was adjusted daily, by infusing water through the polyethylene tubing into the balloon at the rate of $0.2 \mathrm{ml} / \mathrm{sec}$ under ether anesthesia, to the mean volume of the conceptus in intact pregnant rats.

\section{Determinations of intrauterine and intraamniotic pressures}

Under deep ether anesthesia, rats were laparotomized on days 17 and 20, and the pressures in both the balloon and the amniotic sac were determined. During the pressure determination, the abdomen was covered with a piece of gauze saturated with warm saline.

The pressure in the balloon was measured by a pressure transducer (Nihon Kohden, Tokyo, Japan) connected with the balloon tubing. The pressure in the intrauterine balloon fluctuated due to occasional uterine contractions, but a constant basal value was recorded. The balloon was then taken out of the uterine lumen, and the pressure in the extrauterine balloon was also recorded. The difference in pressures between the intra- and extrauterine balloons was defined as intrauterine pressure.

The intraamniotic pressure was measured also by the pressure transducer. A polyethylene tube attached with an injection needle (22G) was inserted into the amniotic cavity through the uterine wall and connected with the transducer. The constant basal value was considered as intraamniotic pressure. This pressure must have been generated by the uterus, because the intraamniotic pressure measured under the atmospheric pressure was below $1 \mathrm{~mm}$ of $\mathrm{Hg}$ on both days 17 and 20. In rats with more than 3 alive fetuses, the mean intraamniotic pressure was calculated on the basis of 2-5 determinations made for conceptuses discontiguous to each other. The pressure determination in each conceptus was completed within $2 \mathrm{~min}$.

\section{Classification of conceptuses}

Conceptuses were classified into 3 groups; normal fetuses without any visible injury, injured alive fetuses or dead fetuses bearing edematous hematomata, and absorbed fetuses in which the fetuses undergoing absorption and the traces of implantations were included. The relative proportion of the 3 types of fetuses in each experimental group was expressed as a percentage against the total number of conceptuses.

\section{Statistical analysis}

Differences in the intrauterine and intraamniotic pressures between experimental groups were evaluated by Duncan's new multiple range test. The significance of the differences in the percentage of the 3 types of fetuses between experimental groups was tested by $\chi^{2}$ analysis using $2 \times 2$ contingency tables.

\section{Results}

Although some rats occasionally showed weak uterine contractions, the basal pressures in the intrauterine balloon and amniotic fluid were 
Table 2. Effects of estradiol $\left(\mathbf{E}_{2}\right)$ and/or progesterone $(\mathbf{P})$ administrations on intrauterine pressure and maintenance of pregnancy in rats ovariectomized (OVX) on day 14 of pregnancy

\begin{tabular}{|c|c|c|c|c|c|c|c|}
\hline \multirow[b]{2}{*}{$\begin{array}{l}\text { Treatment } \\
\text { group* }\end{array}$} & \multirow[b]{2}{*}{$\begin{array}{l}\text { No. of } \\
\text { rats }\end{array}$} & \multirow[b]{2}{*}{$\begin{array}{c}\text { Intrauterine } \\
\text { pressure } \\
(\mathrm{mmH})\end{array}$} & \multirow{2}{*}{$\begin{array}{c}\text { Intraamniotic } \\
\text { pressure }^{t b} \\
(\mathrm{mmHg})\end{array}$} & \multicolumn{4}{|c|}{ Conceptuses } \\
\hline & & & & $\begin{array}{c}\text { Total } \\
\text { no. }\end{array}$ & $\begin{array}{c}\text { Normal } \\
\text { fetus } \\
(\%)\end{array}$ & $\begin{array}{c}\text { Injured } \\
\text { fetus } \\
(\%)\end{array}$ & $\begin{array}{l}\text { Absorbed } \\
\text { fetus } \\
(\%)\end{array}$ \\
\hline \multicolumn{8}{|c|}{ On day 17 of pregnancy } \\
\hline S-OVX & 9 & $4.4 \pm 0.5^{\mathrm{c}}(9)$ & $2.5 \pm 0.4^{\mathrm{c}}(9)$ & 98 & $87.8^{\circ}$ & 0 & $12.2^{\mathrm{c}}$ \\
\hline OVX-V & 8 & $10.3 \pm 0.6^{\mathrm{d}}(7)$ & $11.7 \pm 3.2^{\mathrm{d}}(4)$ & 73 & $30.1^{d}$ & 2.7 & $67.1^{d}$ \\
\hline $\mathrm{OVX}-\mathrm{E}_{2}$ & 8 & $10.5 \pm 1.4^{\mathrm{d}}(7)$ & $7.6,9.3(2)$ & 57 & $15.8^{\mathrm{e}}$ & 0 & $84.2^{\mathrm{e}}$ \\
\hline OVX-P & 7 & $12.8 \pm 0.8^{\mathrm{d}}(6)$ & $9.2 \pm 1.5^{\mathrm{d}}(7)$ & 63 & $92.1^{\mathrm{c}}$ & 0 & $7.9^{\mathrm{c}}$ \\
\hline $\mathrm{OVX}-\mathrm{E}_{2} \mathrm{P}$ & 7 & $6.3 \pm 1 . \mathrm{c}^{\mathrm{c}}(7)$ & $5.0 \pm 0 . \varepsilon^{c}(7)$ & 70 & $81.4^{\mathrm{c}}$ & 0 & $18.6^{\mathrm{c}}$ \\
\hline \multicolumn{8}{|c|}{ On day 20 of pregnancy } \\
\hline S-OVX & 4 & $3.3 \pm 1.1^{\mathrm{e}}(4)$ & $2.2 \pm 0.4^{\mathrm{c}}(4)$ & 37 & $83.8^{\mathrm{c}}$ & ) & $16.2^{\mathrm{e}}$ \\
\hline OVX-V & 4 & $-\quad(0)$ & $-\quad(0)$ & 37 & 0 & ) & $100.0^{\mathrm{d}}$ \\
\hline $\mathrm{OVX}-\mathrm{E}_{2}$ & 4 & $23.0,18.0(2)$ & $(0)$ & 34 & 0 & 0 & $100.0^{\mathrm{d}}$ \\
\hline OVX-P & 4 & $-\quad(0)$ & $15.7 \pm 3.0^{\mathrm{d}}(4)$ & 36 & $27.8^{\mathrm{d}}$ & 22.2 & $50.0^{\mathrm{e}}$ \\
\hline $\mathrm{OVX}-\mathrm{E}_{2} \mathrm{P}$ & 4 & $4.8 \pm 1.3^{\mathrm{c}}(4)$ & $4.3 \pm 2.3^{\mathrm{c}}(4)$ & 30 & $83.3^{\mathrm{c}}$ & 0 & $16.7^{\mathrm{e}}$ \\
\hline
\end{tabular}

*S-OVX; sham-ovariectomized, OVX-V; OVX+vehicle daily, OVX-E $E_{2} ; O V X+0.2 \mu \mathrm{g} \mathrm{E}_{2}$ daily, OVX-P ; $\mathrm{OVX}+4 \mathrm{mg} \mathrm{P}$ daily, OVX $-\mathrm{E}_{2} \mathrm{P} ; \mathrm{OVX}+0.2 \mu \mathrm{g} \mathrm{E}_{2}$ and $4 \mathrm{mg} \mathrm{P}$ daily.

tMeans \pm SEM on the basis of the numbers of determinations indicated in parentheses, or individual values.

a Determined by an intrauterine balloon method.

bDetermined for the conceptus with alive fetus.

c,d,eValues with different superscripts within the same column at each stage of pregnancy are significantly different from each other $(P<0.05)$.

constant. Though intraamniotic pressure was measured by placing a needle through the uterine wall, uterine activity was rarely stimulated by puncturing the uterine wall. Even when the uterine contractions were induced by this procedure, basal pressure in amniotic fluid reached a constant value immediately.

The results are summarized in Table 2. The intrauterine pressure could not be determined frequently in OVX-V, OVX- $\mathrm{E}_{2}$ and OVX-P rats due to the rupture of the uterine wall over the balloon. The intraamniotic pressures in OVX-V and $\mathrm{OVX}-\mathrm{E}_{2}$ rats were not always measurable owing to abortion or absorption of the fetuses.

On day 17 of pregnancy, the intrauterine and intraamniotic pressures in OVX-V rats were markedly higher than those in S-OVX rats respectively. Treatment with estradiol or progesterone alone (OVX-E $\mathrm{E}_{2}$ or OVX-P rats) failed to lower the both intrauterine and intraamniotic pressures, but the pressures in $\mathrm{OVX}-\mathrm{E}_{2} \mathrm{P}$ rats were maintained as low as those in S-OVX animals.

On day 20, the intrauterine pressure in OVX-
$\mathrm{E}_{2}$ rats and the intraamniotic pressure in OVX-P animals were respectively higher than the corresponding value in $\mathrm{S}$-OVX and $\mathrm{OVX}-\mathrm{E}_{2} \mathrm{P}$ rats. The both intrauterine and intraamniotic pressures in $\mathrm{OVX}-\mathrm{E}_{2} \mathrm{P}$ rats were as low as those in S-OVX rats.

In S-OVX and OVX-E $\mathrm{E}_{2} \mathrm{P}$ rats, nearly all the fetuses remained normal until day 20. On the contrary, in OVX-V and OVX-E $E_{2}$ animals less than $30 \%$ of the fetuses were normal on day 17 and all the fetuses were discharged or absorbed by day 20. In OVX-P rats, normal fetuses decreased from $92.1 \%$ on day 17 to $27.8 \%$ on day 20 , and injured fetuses bearing edematous hematomata on their extremities were frequently observed on day 20.

\section{Discussion}

Estrogen and progesterone act synergistically to maintain successful pregnancy in most of the mammals (Courrier, 1950). The present study demonstrates that administrations of combined 
estradiol and progesterone lower the high uterine pressure observed in ovariectomized pregnant rats, while treatments with either of the steroid alone fail to reduce the pressure.

The mechanism of action of estrogen and progesterone for the maintenance of pregnancy is not completely clear. In OVX-P rats, injured fetuses were observed frequently as previously reported (Kroc et al., 1959), and the injuries in these fetuses appeared to be caused by pressing the heads or clunes of the growing fetuses onto the uterine constriction rings under abnormally high pressure (Tamada and Ichikawa, 1980). One of essential roles of estrogen and progesterone to maintain the pregnancy may be lowering of intrauterine pressure during the stage of rapid fetal growth.

According to Fuchs (1978), anesthesia diminishes uterine activity. Under the present conditions of deep ether anesthesia uteri were quiescent, though weak uterine contractions were occasionally observed. Since the basal pressures determined were constant under these conditions, it is not likely that uterine activity influenced these values.

It may be uterine size which determines basal pressure from the uterine wall. In ovariectomized rats estrogen treatment increases the volume of the collagenous framework of the uterus, and progesterone administration tends to inhibit this effect of estrogen (Cullen and Harkness, 1964). In ovariectomized rats whose uteri were distended by the paraffin pellets after parturition, however, estrogen and progesterone maintain cooperatively the length of the collagenous framework of circular uterine strips (Tamada, 1985). Therefore, estrogen and progesterone might act synergistically to develop the collagenous framework of the distended pregnant uteri and keep intrauterine pressure lower.

In almost all the OVX-V, OVX-E $\mathrm{E}_{2}$ and OVX-P rats the uterine wall over the balloon ruptured on day 20. The rupture might have been caused by rapid infusion of water into the balloon. In spite of the increase in the balloon volume, the uterus did not rupture in S-OVX and OVX- $\mathrm{E}_{2} \mathrm{P}$ rats. The uterine tolerance against a rapid in- crease in the inner volume may be developed by both estrogen and progesterone. It is possible that this property has close relation to the size of the collagenous framework.

\section{Acknowledgments}

We thank Dr. C. Chakraborty for editorial help in the preparation of the manuscript. This study was supported by Scientific Research Grant No. 60760240 from the Japan Ministry of Education, Science and Culture.

\section{References}

Courrier $\mathrm{R}$ (1950) Interaction between estrogens and progesterone. Vitam Horm 8: 179-214.

Cullen BM, Harkness RD (1964) Effects of ovariectomy and of hormones on collagenous framework of the uterus. Am J Physiol 206: 621-627.

Fuchs A-R (1978) Hormonal control of myometrial function during pregnancy and parturition. Acta Endocrinol (Suppl.) 89: 221.

Hosoda K, Ichikawa S (1984) Changes of intrauterine pressure in progesterone-treated ovariectomized rats during the second half of pregnancy. Folia Endocrinol Jap 60: 846-851 (in Japanese).

Hosoda K, Tamada H, Ichikawa S (1984) The effect of androgen on the maintenance of pregnancy in progesterone-treated ovariectomized rats. Folia Endocrinol Jap 60: 63-69 (in Japanese).

Ichikawa S, Tamada $H$ (1980) The effect of oestrogen on uterine plasticity in late pregnant rats. $J R e$ prod Fert 58: 165-168.

Kroc RL, Steinetz BG, Beach VL (1959) The effects of estrogens, progestagens, and relaxin in pregnant and nonpregnant laboratory rodents. Ann $N Y$ Acad Sci 75: 942-980.

Tamada H, Ichikawa S (1980) The effect of estrogen on fetal survival in progesterone-treated ovariectomized rats. Endocrinol Japon 27: 163-167.

Tamada H, Yagasaki O, Ichikawa S (1984) The effect of estrogen on passive length-tension relationship in the uterus of ovariectomized progesteronetreated pregnant rats. Int J Fertil 29: 239-243.

Tamada H (1985) Synergistic effect of estrogen and progesterone on the physical properties of the chronically distended rat uterus. Jpn J Anim Reprod 31: 211-215 (in Japanese). 


\title{
エストロジェンとプロジェステロンによるラット妊娠後期
}

\section{における低子宮内圧の維持}

\author{
玉田尋通・中村 裕之・森純一 \\ 大阪府立大学農学部家蓄臨床繁殖学教室, \\ T591 大阪府堺市百舌鳥椎町 4-804
}

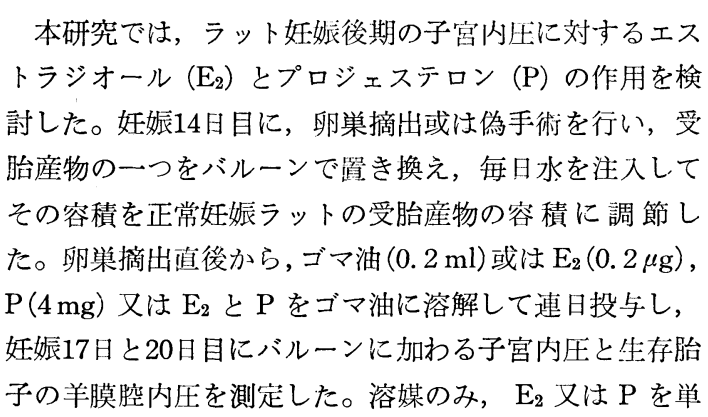

独投与したラットでは，バルーン装着部の子宮壁の破裂 や流産, 胎子の吸収が抗こり, これらの内圧が測定でき ない例があった。 $\mathrm{E}_{2}$ 又は $\mathrm{P}$ の単独投与ラットでは，子 宮内圧及で羊膜腔内圧注何れも溶媒投与ラットと同様な 高い值であったが， $\mathrm{E}_{2}$ と P の併用投与ラットでは，偽 手術ラットと差のない低い值であった。これらの結果か ら, ラット妊娠後期の子宮内圧は, エストロジェン上 $\mathrm{P}$ の協力作用により低く保たれることが示唆された。 